\title{
Assessment of sustainability in urban planning of a coastal city: the city of Coronel, southern Chile
}

\author{
B. Suazo ${ }^{1}$, E. Jaque ${ }^{1}$, C. Rojas ${ }^{2} \&$ R. Utz ${ }^{1}$ \\ ${ }^{1}$ Facultad de Arquitectura, Urbanismo y Geografia, \\ Universidad de Concepción, Chile \\ ${ }^{2}$ Departamento de Geografia, Universidad de Alcalá, Spain
}

\begin{abstract}
Population increases in the coastal area in the Bío Bío region (Chile) have transformed the urban landscape, creating the need for new urban areas for residential land use. This expansion has resulted in the use of locations vulnerable to natural hazards, and outpacing urban planning instruments. The city of Coronel is a typical urban space located in this coastal zone. Coronel's Urban Planning was recently updated in 2003, and the present study's objective is to evaluate its environmental sustainability using a system of indicators applicable to the proposed land coverage model established in the 2003 urban planning instrument.

Urban sustainability indicators are obtained using Geographic Information System (GIS) tools. The indicators are based on three territorial components: the distribution of land use and physical structure, land coverage and environmental quality. The data is gathered in the proposed urban land zonings. The method applies sustainability development concepts in data modeling, spatial analysis and geoprocessing in GIS. The results characterize the proposed urban model's sustainability.
\end{abstract}

Keywords: sustainability indicator, urban planning, GIS.

\section{Introduction}

Urban planning is a public sector tool of increasing importance used to achieve competitiveness and habitability in Chilean cities. Considering that one of the principal objectives of urban planning is to orient a territory's development 
harmonically with its surroundings, its importance is undeniable considering Chile's present level of development. In this context, Coronel County, located on the Pacific coast in the Bio Bío region $\left(37^{\circ} \mathrm{S}\right.$ and $\left.73^{\circ} 0^{\prime}\right)$, presented a new urban zoning plan [1].

The organization and use of county territory is defined in a development policy that valorizes land resources, climate and landscape in order to promote investment in the productive, industrial and tourism sectors. The concept of sustainability intrinsically connects economic growth, environmental protection and social equity. The County of Coronel has evolved and changed in the last few years due to the crisis in coal mining and the growth of new productive industrial activities, resulting in a new scenario of county and urban growth, and consequently new urban planning. This transformation required a reconsideration of the image of the city of Coronel in order to more effectively use its resources, such as a strategic geographic location in southern Chile, land appropriate for industrial development, a natural protected port, fishing, forests, and a consolidated urban area with history and cultural heritage.

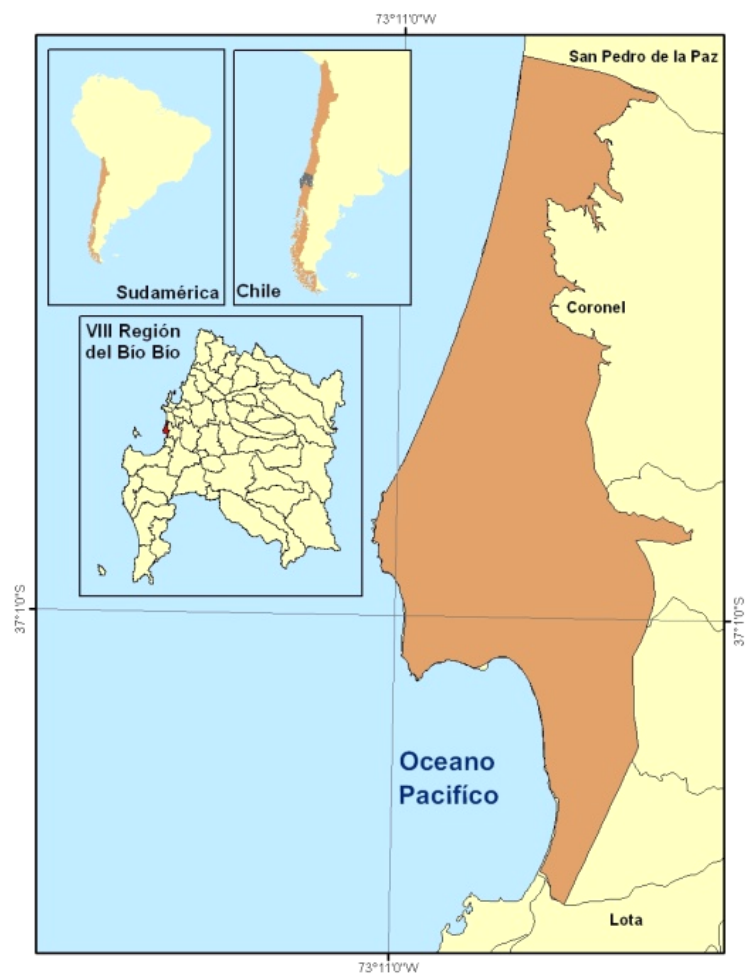

Figure 1: Geographic location of Coronel County.

The reformulation of the Regulating Plan was principally oriented to favor the growth of economic and social activities in the city based in compatible interests between public and private actors to preserve the quality of Coronel's 
urban and county environment to establish patterns and standards of sustainable quality by adequately zoning the territory, ordering the structuring roads, defining the expansion areas, determining urban limits and establishing infrastructure in convenient locations.

In the last few years, planners and scientists have studied cities from a sustainability perspective, finding that actual urban growth patterns have produced environmental, social and economic costs. In this area, an especially interesting challenge is the identification of conceptually and methodologically solid procedures to measure sustainability in territorial city models. In the last few years, the principal initiatives have been developed by different governments that seek to identify unsustainable patterns and tendencies in urban growth.

The concept of urban sustainability is widely used, although it remains a complex, quite vague term because cities present distinct characteristics and economic models. Urban sustainability is generally understood as equilibrium between a city's environmental, economic, and social aspects without degrading the urban environment, and thus assuring urban life quality [2]. Urban sustainability offers adequate habitability conditions, satisfies habitant necessities, and respects the urban environment.

The literature has identified several factors that favor greater urban sustainability. According to Franchini and Dal Cin, Rueda and Maestu [3-6] the attributes of a sustainable city are:

- Rational land use, seeking to reduce urban expansion and promoting recycling of preexisting urban tissues and avoiding low-density urban developments.

- A connection between growth necessities and the preservation of natural and cultural values. A compact, manageable urban structure.

- An infrastructure organization that facilitates interaction between citizens and an equitable distribution of resources.

These attributes reflect an approximation of a sustainable city model, although we need to address the externalities of a compact city and the high density levels. The compact model, widely offered in Europe, in the 1980s, as the most sustainable city model, results in a concentration of activities generating environmental impacts, such as noise and pollution, which are referred to as the "paradox of the compact city" [7]. In Latin America, the large urban areas are dispersing and the models of life quality are now associated to low density residential models and are found at a greater distance from downtown and its problems. Still, a compact city is more sustainable because it is a dense, continuous, multifunctional, heterogeneous and diverse city. As a result, it offers internal complexity, cohesive social life, savings in land, energy and resource use as well as agricultural and natural system preservation [4, 8].

Considering the growing concern for urban health, it is interesting to analyze the operative measures and advances in the conditions that can be used to optimize it. In this sense, sustainability indicators, which are accepted by politicians and academics to measure the advances in sustainability in a given territory, will provide information and facilitate communication between experts, decision makers, and the public in general [9]. Indeed, they reflect one of the 
greatest efforts of urban settlements to evaluate their progress towards sustainable development [10].

Most countries have adopted the most successful models, such as the PSR (Pressure - State - Response) and/or FSR (Motor Force - State - Response) models. These indicators have been mainly used in national and regional studies [11]. In the case of cities, two types of indicators have been used in the literature: urban sustainability indicators for evaluation and diagnostics and sustainability indicators for (prospective) city planning. In city diagnostics, the studies of Shane and Graedel [12], Romero, Vásquez [13], Bolocco and Grazzini [14] and Pauchard [15] are important. While in the area of planning indicators, the proposal of Carsjens and Ligtenberg [7].

The lack of consensus with respect to the validity of sustainability indicators has limited their use. Some reflections suggest that they are only useful in measuring non-sustainability in a city's development model without providing efficacious solutions, and thus the demonstration of non-sustainability is more important that the search for sustainability [2]. Indeed, Escolano [16] argues that there is no accepted systematic set of indicators to measure urban sustainability. Additionally, the diversity of contexts, both territorial and socioeconomic, requires the establishment of specific measures for each case. Still, a discussion of general concepts, problem components, sustainability attributes and criteria, and their inter-relation is required to evaluate urban models.

In our case studies of Spanish and Chilean cities, we have used territorial indicators based in Geographical information systems (GIS), where these are understood as those that measure spatial differences of any phenomenon as well as those that recognize these differences as a consequence of the spatial structure of land use, transport networks, resource locations, and residential typologies. In other words, these indicators fundamentally evaluate territorial model sustainability rather than land use sustainability. For more information on prior results and reflections, please see Salado et al. [17], Rojas et al. [18], Díaz et al. $[19,20]$ and Rojas and Díaz [21].

\section{Methodology}

Urban sustainability indicators are a set of spatial measures applied in urban planning as represented in the County Zoning Plan. They should be relevant, easily understandable, reliable, scientifically valid, and based in accessible, interesting to inform society. In general, they should respond to detected necessities or problems or they should be simply intuitive in order to identify and arbitrate solutions [2]. These indicators are generally processed and quantitative, generating clear, accessible ideas on complex phenomenon, its evolution and the breach between the actual and desired situation [11]: in our case, the land use model for local urban planning. The attributes of sustainable urban planning are adapted to the city model proposed in the plan's urban zoning and they are the conditions that should be strengthened.

Communal zoning in Chile defines the consolidated urban land, urbanizable land, and non-urbanizable land. In our opinion, it is sustainable if in: 
Consolidated urban land exists when there is a compact, spatially continuous urban structure; mean residential densities; optimized urban land; reuse, urban renewal, recovery of degraded and abandoned areas; mixture of land use, spatial co-existence of residential with functional uses or useful non-residential uses (public services, commerce and other), facilitate the spatial integration of residential uses. Avoiding third uses that do not reduce residential use; mobility and integrated public transportation integrated to land uses, and cultural heritage conservation.

Urbanizable land use areas are those that have mean and low residential densities; avoid disperse and/or diffuse growth; allow permeable growth, avoiding the obstacle formation; avoid the proximity of incompatible uses; avoid the occupation in risk areas; respect very fertile agricultural and forestry land use and valuable rural spaces; maintain landscapes without degrading them; are transitions zones between urban and rural areas that provide a space reserve for growth.

Restricted land use areas are oriented to conserving biodiversity and natural heritage; preventing the occupation of natural and technological risk areas; preserving areas with high productive agricultural, forestry, or landscape value; protecting water systems. As a complement, infrastructure areas and green areas should supply the population and respond to a good spatial localization.

They are organized in three components: distribution of land use and physical structure; land use; and environmental quality. Spatial measures evaluate the proposed city-planning model in order to contribute to new methodologies. In this sense, GIS offers the possibility of calculating and modeling indicators, manipulating territorial information layers.

\section{Results}

\subsection{Coronel city in the regional context}

Coronel is located south on the lower part of the Bio Bío River. Coal mining consolidated Coronel as a city in 1851. Federico Schwager initiated coal mining activities in 1859 in Puchoco and Maule, and small urban areas were built as copies of English "Company Towns". From 1865 until the first half of the $20^{\text {th }}$ Century, Coronel peaked in economic and urban development. Together with the nearby city of Lota, they were the center of coal mining. Coronel surged as a vigorous commercial port, around which its principal activities were organized in the downtown. Designed as an orthogonal reticule, it supplied a large part of the counties in the Arauco Province.

Between 1950 and 1970, large populations were built in the northern part. In the 1970s, the neighborhoods Lagunillas and Villa Mora were created together with others in the sector of Schwager. The coal boom unleashed important internal migrations and strong urban growth, resulting in indiscriminate cutting of surrounding forests in order to install housing and industrial parks, decreasing protection of slopes and plateaus. 
In the 1960s, an earthquake and the progressive drop in the world's coal demand contributed to the deterioration of Coronel as an urban center, increasing its environmental and social degradation. At the end of the 1970s, the city was strongly contaminated due to the Concepción - Lota highway that longitudinally crosses the city. With a collapsing downtown area, its mining industry dying, its port with low activity, the population faced high poverty indexes (CASEN 2006) This situation was especially difficult in the 1980s and 1990s with the definitive and progressive closing of the coal mines, which were the principal source of employment during the last 150 years.

At the end of the $20^{\text {th }}$ century, Coronel's environmental reality is unsustainable principally because the principal public spaces in downtown have been strongly degraded and the principal beach (Playa Blanca) has been strongly impacted by industrial waste. The city's linear development is structured around axes, obligating extension of infrastructure and basic services without protecting dunes, hillsides, and water courses [22]. Finally, from the mid-1990s until the beginning of the $21^{\text {st }}$ Century, the county has experienced a growing development of new industrial productive activities. As a result, Coronel has a distinct relation with communities neighboring Concepción, generating a new development scenario now considered in the new County Planning instrument.

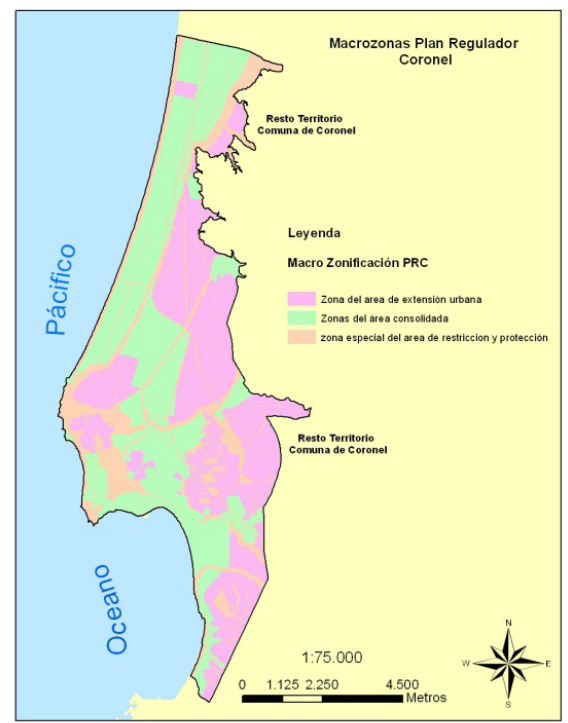

Figure 2: $\quad$ Macro plan area regulator.

At present, due to demographic growth and its historical development, Coronel is a city segmented between the older section (initial reticule) linked to mining development and the newer sector (nearby neighborhoods) that emerged in the 1970s as a response to the growing population dedicated to other productive (industrial park) and service activities, resulting in sectored, partial growth. It is a markedly linear, extensive city (central structure is $8 \mathrm{~km}$ in 
length) that grows towards the north, losing its centrality. Coronel extends horizontally through publicly funded high-density neighborhoods (SERVIU), which occupy almost the entire territory while offering scarce public spaces. This growth towards the north of the territory has created commuting problems as well as deficient roads, health and other infrastructures.

The County of Coronel has a habitable surface area of 10,187 hectares, corresponding to $36.5 \%$ of the county. A total of 980 hectares of the habitable surface area is actually used for housing, 907.5 hectares for industrial use, and 423 hectares corresponds to diverse types of port areas. As a result, approximately $24 \%$ of the habitable surface area is available, and the sectors corresponding to consolidated areas present higher occupation densities with the periphery and sub-urban sectors presenting lower densities (between 5 and 1.5 hab/ha).

The Regulator Plan defines four macro-areas to regulate the County's territorial organization CONSOLIDATED AREA: This area defines and promotes residential, productive, recreation, and mixed uses, favoring greater density and growth.

URBAN EXTENSION AREA: These areas are located outside of the present urban limit and whose densification will regularize already existing edifications and the County's consolidate urban growth.

SPECIAL RESTRICTION AND PROTECTION AREA: These areas are developed in the sectors whose natural condition inhibits presence of urban development. In this sense, the proposed Regulator Plan seeks to define the areas with the greater vulnerability to natural risks, and consequently establishes standards to regulate its uses. Special measures are included to encourage development while assuring the habilitation and correction of the deficiencies present. Additionally, these areas are defined to assure historic conservation or due to the location of potable water, electric and prison services infrastructure.

\subsection{Analysis of indicators}

The indicators applied are: population density, soil use, distance from basic services, urbanizable surface areas in areas unapt for urban growth, nonconstructed land, and protected land, population vulnerable to natural disasters, surface area vulnerable to natural disasters, land protected for its natural value, and population within 500 meters of green areas. The unit of analysis is the regulator plan's 5 zoning areas: Consolidated zones, urban extension zones, restriction and protection zones, Productive activities and equipment areas, and public space and green areas.

The average population density in Coronel's urban area is the following. An average of $31.1 \mathrm{hab} / \mathrm{ha}$ was found in consolidated areas, ranging between 80.32 hab/ha in residential zone 1 and 73.9 hab/Ha. In Residential zone 2. In contrast, the expansion zones present an average density of $5.2 \mathrm{Hab} / \mathrm{ha}$. When analyzing the use mixture, the residential areas are found in the consolidated areas. According to the parameters, there is not a homogeneous mixture of uses; services are concentrated in consolidated areas. Nearness to both educational and health services are located in two centralities, where a new central nucleus, 
located in the Camilo Olabarría sector, is clearly emerging and is becoming more important than the traditional city center.

Among the more interesting criteria or indicators from the environmental sustainability perspective are the natural risk areas and population with natural risks. Our results generated by the IPT indicate that $67.2 \%$ of the actual urban surface area presents natural risks, where $38.4 \%$ corresponds to the risk of mass movement, $17 \%$ land sinking, and $11.8 \%$ to flooding. Additionally, a total of 91,469 personas are exposed to natural risks (INE, 2002), 16,862 persons $(18.4 \%)$ live in danger zones with the following characteristics: $12.4 \%$ risk of mass movement and $5.6 \%$ risk of land sinking, where $4.6 \%$ of these are simultaneously exposed to land sinking and mass movement and $7.8 \%$ are located only in mass movement areas. Finally, 5\% of urban Coronel faces the possibility of flooding. The Plan defines $15.24 \%$ of the urban area as natural risk protection areas, and thus $51.9 \%$ of the urban area that presents natural risks has been maintained as a residential area.

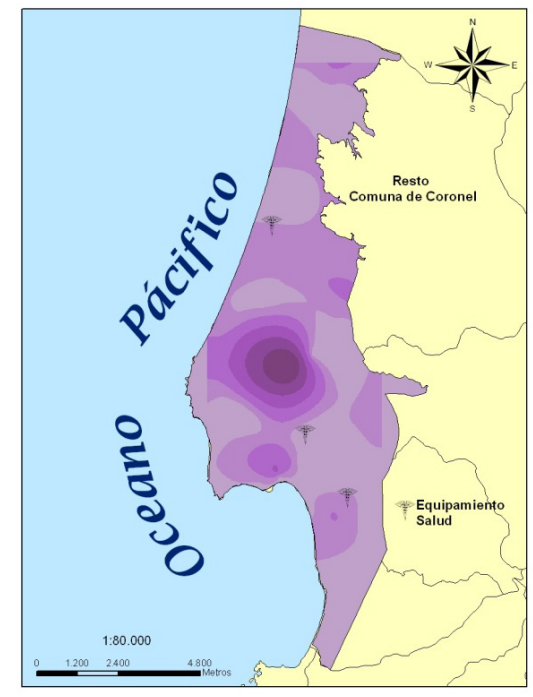

Figure 3: Distances to educational equipment.

\section{Discussion}

The indicator system provides a general vision with respect to the sustainability conditions of the new urban limit in aspects exclusively territorial or spatial of the city's territorial model. The Plan's efficacy and impacts in the aspects measured will be observed in time, where sustainability is given by a set of factors, independently of whether the Plan's proposals for areas or infrastructure are or not implemented. 
The definition of the Plan's permitted and non-permitted uses does not sufficiently transform the city's possibility of sustainability. A regulator plan, in addition to addressing in depth the aspects with respect to construction, it should also indicate that proposed city model that responds to both economic and housing pressures and is framed within a concept of sustainable urban planning.

With respect to the use of Geographic Information Systems in the obtainment and modeling of indicators, information must be adequately obtained, an aspect that is not completely addressed in Chilean planning instruments. At present, the GIS data coming from the regulator plan require platforms that are inter-operable between CAD and GIS as well as the possibility of correction between formats. One solution could be the Geodatabase model, where the application of topologies and metadata generation are more attractive.

The study pretends to be a contribution to the models evaluating sustainability in cities, and fundamentally in urban planning of mid-sized cities, such as many in Chile. These methodologies can be integrated into the IPT elaboration process, and thus the zoning proposals will respond more efficiently to global sustainability criteria. Since the Regulator Plan is a key instrument for city development-indeed, it is the urban planning instrument with the most impact and competence in a city's development. Thus, it is increasingly necessary that it become a strategic instrument based in a sustainable urbanism perspective rather than just a plan that regulates the construction of urbanized and urbanizable space.

\section{Conclusions}

This study worked with indicators that measure city sustainability. Although these indicators are not new in their definition because there is a wide spectrum and measurement types, they are novel in their application to territorial planning of land use as proposed in Coronel's PRC, especially in the measurements within the zonings. The indicator system based in sustainable urban planning attributes and in the territorial components of density, land use, and environmental quality was interesting and perfectly applicable in any Chilean Communal Regulator Plans. Coronel's PRC defined urban land, urbanizable land, restricted and protected land. Using the defined indicators, we were able to analyze its coherence with the attributes of sustainable urban planning. Due to the lack of future land use derived from the zonification, the sustainability evaluation depends on the actual and future uses although it is unable to obtain greater details on the proposed uses.

Even when the zone definitions in the respective ordinance includes permitted land uses, prohibited land uses, occupation coefficient, densities, and property surface areas, these specifications are not limited within the zones. In other words, they are not spatially located on a map, and thus the proposed type of city is not clearly observable.

The plan advances in certain sustainable urban planning aspects, such as the conservation of cultural heritage, the restriction of industrial uses that are incompatible with residential uses. However, one of the indicators that marked 
the analysis was the population in risk. There was prohibition of occupation in areas considered to have natural risk or landscape value. However, there were only weak restrictions for urban use on the coast, there was no concrete zoning for flood risk areas or the restrictions were based on unreliable data.

\section{References}

[1] Ministerio de Vivienda y Urbanismo (2002). Chile

[2] González, M.J., De Lázaro \& Torres, M.L. (2005). Indicadores Básicos para la Planificación de la Sostenibilidad Urbana Local. Revista Bibliográfica de Geografía \& Ciencias Sociales Bibio 3W X.

[3] Franchini, T \& Dal Cin, A. (2000). Indicadores urbanos y Sostenibilidad. Hacia la definición de un umbral de consumo sostenible de suelo. Ciudad y Territorio Estudios Territoriales 123, 41-55.

[4] Rueda, S. (2002). Barcelona, ciudad mediterránea, compacta y compleja: una visión de futuro más sostenible. Ayuntamiento de Barcelona Agencia de Ecología Urbana

[5] Rueda, S. (2004). Modelos de Ordenación del territorio más sostenibles. Revista de Geografía y Ecología

[6] Maestu, J., Prats, F., Velásquez, I., Del Acamara, G., Blanco, I., Rodríguez, M., Disougi, M \& Naredo, M. (2003). Bases para la evaluación de la sostenibilidad en proyectos urbanos, Madrid.

[7] Carsjens, G \& Ligtenberg, A. (2006). A GIS - based support tool for sustainable spatial planning in metropolitan areas. Landscape and Urban Planning.

[8] Ministerio de Medio Ambiente Gobierno de España (2006). Estrategia de Medio Ambiente Urbano. En: Ambiente, M.d.M. (Ed.).

[9] Alberti, M. \& Susskind, L. (1996). Managing Urban Sustainability: An Introduction to the Special Issue. Environmental Impact Assessment Review 16, 213-221.

[10] Ooi, G. (2005). Sustainability and Cities Concept and Assessment, Singapore.

[11] Blanco, H., Wautiez, F., Llavero, A. \& Riveros, C. (2001). Indicadores de desarrollo sustentable en Chile: Hasta qué punto son útiles y necesarios? Estudios urbanos regionales EURE 27, 85-95.

[12] Shane, M \& Graedel, T. (2000). Urban Environmental Sustainability Metrics: A provisional Set. Journal of Environmental Planning and Management 43, 643-663.

[13] Vásquez, A., Riveros, S \& Romero, H. (2005). Sustentabilidad del Desarrollo Urbano del Gran Concepción. In: Geográficas, S.C.d.C. (Ed.), XXVI Congreso Nacional y XVI Congreso Internacional de Geografía Pontificia Universidad Católica de Chile Santiago de Chile.

[14] Bolocco, C \& Grazzini, G. (2006). Sustainability and information in urban system analysis. Energy Policy 34, 2905-2914.

[15] Pauchard, A., Aguayo, M., Peña, E \& Urrutia, R. (2006). Multiple effects of urbanization on the biodiversity of developing countries: The case of a 
fast - growing metropolitan area (Concepción, Chile). Biological Conservation 127, 272-281.

[16] Escolano, S. (2002). Densidad de población y sustentabilidad en la ciudad de Zaragoza. En: AAVV (Ed.), Aportaciones geográficas en memoria del profesor Miguel Yetano Ruiz. Departamento de Geografía y Ordenación del Territorio de la Universidad de Zaragoza, Zaragoza, pp. 173-182.

[17] Salado, M.J., Díaz, M.Á., Bosque Sendra, J., Cantergiani, C., Rojas, C., Jiménez, F., Barnett, I., Fernándes, C \& Muñoz, C. (2005). "Movilidad Sostenible y SIG". Propuesta de evaluación del transporte público en Alcalá de Henares". En: Camacho, M., Cañete, J., Lara, J. (Eds.), El acceso a la información espacial y las nuevas tecnologías geográficas. Grupo de Tecnologías de la Información Geográfica de la Asociación de Geógrafos Españoles y Universidad de Granada, pp. 1777-1794.

[18] Rojas, C., Díaz, M.Á \& Jaque, E. (2006). Diseño de un sistema de indicadores de planeamiento urbano sostenible aplicado al Plan Regulador Comunal de Tomé. Anales Sociedad Chilena de Ciencias Geográficas 184 189.

[19] Díaz, M.Á., Cantergiani, C., Salado, M.J., Rojas, C \& Gutiérrez, S. (2007a). Propuesta de un sistema de indicadores de sostenibilidad para la movilidad y el transporte urbanos. Aplicación mediante SIG a la ciudad de Alcalá de Henares. Cuadernos de Geografía Universidad de Valencia.

[20] Díaz, M.Á., Salado, M.J., Rojas, C., Cantergiani, C \& Gutiérrez, S. (2007b). Sobre la sostenibilidad de los Modelos Territoriales Urbanos. Experiencias y Reflexiones. Boletín de la Real Sociedad Geográfica CXLII.

[21] Rojas, C \& Díaz, M.Á. (2007). Hacia la Evaluación de la sostenibilidad del Desarrollo Urbano. Propuesta de un sistema de indicadores soportados en SIG y aplicación al modelo de Ocupación de Suelo establecido en el Plan Regulador de la ciudad de Tomé. XX Congreso de Geógrafos Españoles "La Geografía en la frontera de los conocimientos". Universidad Internacional de Andalucía Asociación de Geógrafos Españoles y Universidad Pablo de Olavide.

[22] Zelada, 2002. Plan Regulador Comunal de Coronel 